\title{
Relationship between carcass composition and first oestrus in Romney ewe lambs
}

\author{
R. W. Moore, J. J. Bass*, G. W. Winn* and H-U. P. Hockey* \\ Whatawhata Hill Country Research Station, and * Ruakura Agricultural Research Centre, Ministry \\ of Agriculture and Fisheries, P.B., Hamilton, New Zealand
}

\begin{abstract}
Summary. Weaned Romney ewe lambs were grazed at two levels of nutrition from 20 December to 12 April. Both groups were grazed together at a high level of nutrition thereafter. Vasectomized rams were introduced on 1 April. Oestrus occurred in 62/84 $(74 \%)$ of the low nutrition group and in all 24 of the high nutrition group. The mean date of first oestrus was 3 June for the former and 28 May for the latter. The non-oestrous ewes were killed on 17 July and the others within 5 days of showing oestrus. From each carcass, certain organs (i.e. adrenals, ovaries, thyroid, heart, kidneys, liver, lungs, spleen, stomach and uterus) and various fat depots were dissected out and weighed. In addition, half of the carcass was minced and subsampled for protein and fat analysis.

The weight of uterus discriminated between oestrous and non-oestrous animals, as did a linear combination of the weights of lungs, spleen and stomach. The data suggest that fatness or protein content, or the weights of the other organs, are not important indicators of sexual maturity in female sheep.
\end{abstract}

\section{Introduction}

The oestrous season for Romney ewe lambs extends from late April to mid-July in New Zealand, the onset being about 6 weeks after that of the mature ewe (Hight, Lang \& Jury, 1973). Although mean liveweight is a useful predictor of the incidence of oestrus in a group of ewe lambs (Moore \& Smeaton, 1980), first oestrus can occur in the range of $25-40 \mathrm{~kg}$ ( R. W. Moore, unpublished).

There is evidence relating fat and protein composition to puberty in the females of other mammals. Frisch \& McArthur (1974) have claimed that menarche in girls is associated with a minimum proportion of body fat $(17 \%)$. Frisch, Hegsted \& Yoshinaga (1977) found that rats fed on high and low fat diets had the same weight of fat in their bodies at first oestrus and those on the high fat diet showed oestrus earlier and at a lighter weight. Wilen \& Naftolin (1977) found an association between body protein content and first oestrus in rats.

In this paper the possibility that some body composition trait was related to the occurrence of oestrus was investigated for ewe lambs. Part of this work has been published in abstract form (Moore, Bass \& Winn, 1981).

\section{Materials and Methods}

\section{Experimental}

Ewe lambs with a mean birth date of 31 August (range 16 August-13 September) were divided into two matched groups on 19 December and grazed until 12 April at different pasture allowances giving intakes of about 1.25 and $0.75 \mathrm{~kg}$ dry matter per ewe per day. All ewes had intakes of about 1 $\mathrm{kg}$ dry matter per day thereafter. The object of the different levels of nutrition immediately after weaning was to ensure that some lambs showed oestrus while others did not. Nutrition during this 
period affects the probability of a lamb showing oestrus over and above the nutritional effects on live weight (Moore \& Smeaton, 1980). Harnessed vasectomized rams were introduced on 1 April and tup marks were recorded 3 times weekly. Ewes were killed 0-5 days after their first oestrus. Ewes that failed to show oestrus were killed on $17 \mathrm{July}$. After overnight fasting the lambs were weighed and then slaughtered according to commercial practice in New Zealand (Kirton, Dalton \& Ackerley, 1974). The hot weight of the carcass was recorded and the following organs and glands were dissected out and weighed: adrenals, ovaries, thyroid, heart, kidneys, liver, lungs, spleen, stomach (including reticulum, rumen, omasum and abomasum), and uterus (without cervix). The frozen carcass was halved longitudinally. The left side was minced and subsampled for chemical determination of protein and fat (Kirton \& Pickering, 1967). From the right side the internal fat (the fat lining of the abdominal cavity minus the kidney fat) and kidney fat were dissected out and weighed. From the right hind-quarter the weights of subcutaneous and intermuscular fat, and 8 major muscles ( $M$. gluteus medius, $M$. biceps femoris, $M$. semimembranosus, $M$. semitendinosus, $M$. quadriceps femoris, $M$. psoas major and minor, $M$. longissimus dorsi) were obtained. Cannon bone length was also recorded.

\section{Statistical analysis}

Principal component analysis (Press, 1972) was used to select a subset of traits representative of the total variation in the body composition traits. Logistic regression modelling of binomial data was then used to find out whether this subset could provide discrimination between oestrous and non-oestrous animals (Press \& Wilson, 1978). A logistic regression equation was also formed using the weights of 3 organs as the predictor variables. These equations give the predicted probability of success (defined as showing oestrus) in a binomial trial. The closer this probability is to 1 the more likely the animal is to show oestrus, and when below 0.5 the animal is expected not to show oestrus.

\section{Results}

All (24/24) of the high nutrition group showed oestrus, the mean date being 25 May, with a range of 67 days from 11 May to $17 \mathrm{July}$. In the low nutrition group the incidence of oestrus was $74 \%(62 / 84)$, and the mean date of first oestrus was 3 June with a range of 63 days from 30 April to $2 \mathrm{July}$. The ewes were classified into 3 types; the high nutrition-oestrous group, the low nutrition-oestrous group, and the low nutrition-non-oestrous group.

Regression equations for the 3 types were calculated with total or \% fat as the dependent variables and hot carcass weight and age as the independent variables. These equations showed that age had no relationship with total or $\%$ fat when corrected for hot carcass weight (Table 1 ).

Mean values for the 3 different types for the traits studied are given in Table 2 . The F-test for

Table 1. Relationships between $\mathrm{kg}$ of total or $\%$ fat $(y)$ and $\mathrm{kg}$ of hot carcass weight (HCW) and age at death (AGE) for the three groups of ewe lambs

\begin{tabular}{|c|c|c|}
\hline Group & Total fat & $\%$ Fat \\
\hline High nutrition-oestrous & $\begin{array}{c}y=\underset{(2.47)}{-0.81}+\underset{(0.05)}{0.41} \mathrm{HCW}-0.0 .006 \mathrm{AGE} \\
(0.010)\end{array}$ & $y=\underset{(15.3)}{20.1}+\underset{(0.34)}{1.20} \mathrm{HCW}-\underset{(0.06)}{0.05} \mathrm{AGE}$ \\
\hline Low nutrition-oestrous & 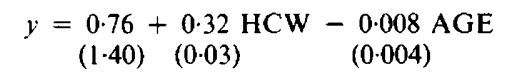 & $y=\underset{(9.2)}{26.4}+\underset{(0.19)}{0.69} \mathrm{HCW}-\underset{(0.03)}{0.05} \mathrm{AGE}$ \\
\hline Low nutrition-non-oestrous & $\begin{array}{c}y=-\frac{-3.96}{(5.36)}+\underset{(0.05)}{0.43} \mathrm{HCW}-0.002 \mathrm{AGE} \\
(0.016)\end{array}$ & $y=\underset{(31.2)}{2.2}+\underset{(0.32)}{1.28} \mathrm{HCW}-\underset{(0.10)}{0.0006} \mathrm{AGE}$ \\
\hline
\end{tabular}

Values in parentheses are the standard error of the coefficient. 
Table 2. Mean values for liveweight (LW), cannon bone length, hot carcass weight and different components of carcass weight in 3 types of ewe lambs (all means except liveweights are adjusted for slaughter weight)

\begin{tabular}{|c|c|c|c|c|c|}
\hline \multirow[b]{2}{*}{ Trait } & \multicolumn{3}{|c|}{ Group } & \multirow[b]{2}{*}{ s.e.d. } & \multirow[b]{2}{*}{ Significance $\dagger$} \\
\hline & $\begin{array}{c}\text { High } \\
\text { nutrition- } \\
\text { oestrous }\end{array}$ & $\begin{array}{c}\text { Low } \\
\text { nutrition- } \\
\text { oestrous }\end{array}$ & $\begin{array}{l}\text { Low } \\
\text { nutrition-non- } \\
\text { oestrous }\end{array}$ & & \\
\hline Numbers & 24 & 62 & 22 & & \\
\hline \multicolumn{6}{|l|}{ Liveweights } \\
\hline \multicolumn{6}{|l|}{$\begin{array}{l}\text { Period with } 2 \text { levels } \\
\text { of nutrition }\end{array}$} \\
\hline LW at start $(\mathrm{kg})$ & $21 \cdot 2$ & $21 \cdot 7$ & $21 \cdot 3$ & 0.95 & NS \\
\hline LW at end $(\mathrm{kg})$ & $28 \cdot 2$ & $27 \cdot 2$ & $24 \cdot 1$ & 0.95 & $* * *$ \\
\hline LW at slaughter $(\mathrm{kg})$ & 31.9 & 31.5 & $33 \cdot 4$ & 0.90 & NS \\
\hline \multicolumn{6}{|l|}{ Carcass composition } \\
\hline Cannon bone length $(\mathrm{cm})$ & $10 \cdot 5$ & $10 \cdot 4$ & $10 \cdot 6$ & $0 \cdot 10$ & NS \\
\hline Hot carcass wt $(\mathrm{kg})$ & 14.9 & 14.6 & $15 \cdot 6$ & 0.55 & NS \\
\hline Fat $(\%)$ & $23 \cdot 4$ & 22.5 & $21 \cdot 6$ & 0.70 & NS \\
\hline Protein $(\%)$ & $17 \cdot 2$ & $17 \cdot 1$ & $17 \cdot 2$ & 0.21 & NS \\
\hline Water $(\%)$ & 53.8 & 54.9 & 55.9 & 0.60 & $*$ \\
\hline Total fat $(\mathrm{kg})$ & 3.46 & $3 \cdot 34$ & 3.26 & $0 \cdot 13$ & NS \\
\hline Total protein $(\mathrm{kg})$ & $2 \cdot 52$ & $2 \cdot 54$ & 2.55 & 0.37 & NS \\
\hline Total water $(\mathrm{kg})$ & 7.88 & $8 \cdot 11$ & $8 \cdot 27$ & $0 \cdot 11$ & $*$ \\
\hline Internal fat $(\mathrm{g})$ & 91.7 & $96 \cdot 1$ & 76.7 & 5.9 & ** \\
\hline Kidney fat (g) & 291 & 302 & 252 & 21 & NS \\
\hline \multicolumn{6}{|l|}{ Hindquarter composition } \\
\hline Subcutaneous fat (g) & 407 & 395 & 384 & 20 & NS \\
\hline Intermuscular fat (g) & 225 & 217 & 206 & 10 & NS \\
\hline Total muscle (kg) & $1 \cdot 31$ & $1 \cdot 34$ & $1 \cdot 35$ & 0.02 & NS \\
\hline \multicolumn{6}{|l|}{ Organs } \\
\hline Adrenals (g) & 2.95 & 2.69 & 2.81 & $0 \cdot 11$ & NS \\
\hline Ovaries $(\mathrm{g})$ & $1 \cdot 20$ & $1 \cdot 22$ & 0.98 & 0.07 & ** \\
\hline Thyroid (g) & $2 \cdot 23$ & 2.57 & 2.42 & $0 \cdot 17$ & NS \\
\hline Heart $(\mathrm{g})$ & 168 & 181 & 186 & 6.0 & * \\
\hline Kidneys (g) & 105 & 106 & 106 & 1.9 & NS \\
\hline Liver $(\mathrm{g})$ & 565 & 571 & 544 & 13 & NS \\
\hline Lungs $(g)$ & 547 & 570 & 627 & 18 & $* * *$ \\
\hline Spleen (g) & $44 \cdot 7$ & $50 \cdot 5$ & $64 \cdot 4$ & $2 \cdot 4$ & $* * *$ \\
\hline Stomach $(\mathrm{kg})$ & 1.08 & 1.08 & 0.99 & 0.03 & ** \\
\hline Uterus (g) & $19 \cdot 4$ & 16.9 & 8.6 & 1.2 & $* * *$ \\
\hline
\end{tabular}

$\dagger$ F-test for differences between the 3 group means: ${ }^{*} P<0.05,{ }^{* *} P<0.01,{ }^{* * *} P<0.001$.

differences amongst the three means was significant for the 11 April liveweight, and the percentage and weight of water, internal fat, ovaries, heart, lungs, spleen, stomach and uterus. For all these traits, except weight of heart, the rejection of the hypothesis of equal means was due mainly to the differences between oestrous and non-oestrous lambs.

If any trait or linear combination of traits provided good discrimination between oestrous and non-oestrous ewe lambs then a graph of this discriminator against age would resemble Text-fig. 1(a). The points to the top left would be those ewes showing oestrus and slaughtered soon after, while the remaining points would be the non-oestrous lambs slaughtered in mid-July. Text-figures 1(b) and (c) show that neither fat nor protein are useful indicators of oestrus, while Text-fig. 1(d) shows some relationship between uterine weight and oestrus. The other traits gave results similar to fat and protein.

The five traits (subcutaneous, internal and intermuscular fat, protein and muscle) were found to be representative of the variation in the carcass composition traits and were used to form a logistic regression equation predicting the probability of oestrus for each animal. The fitted probability has 

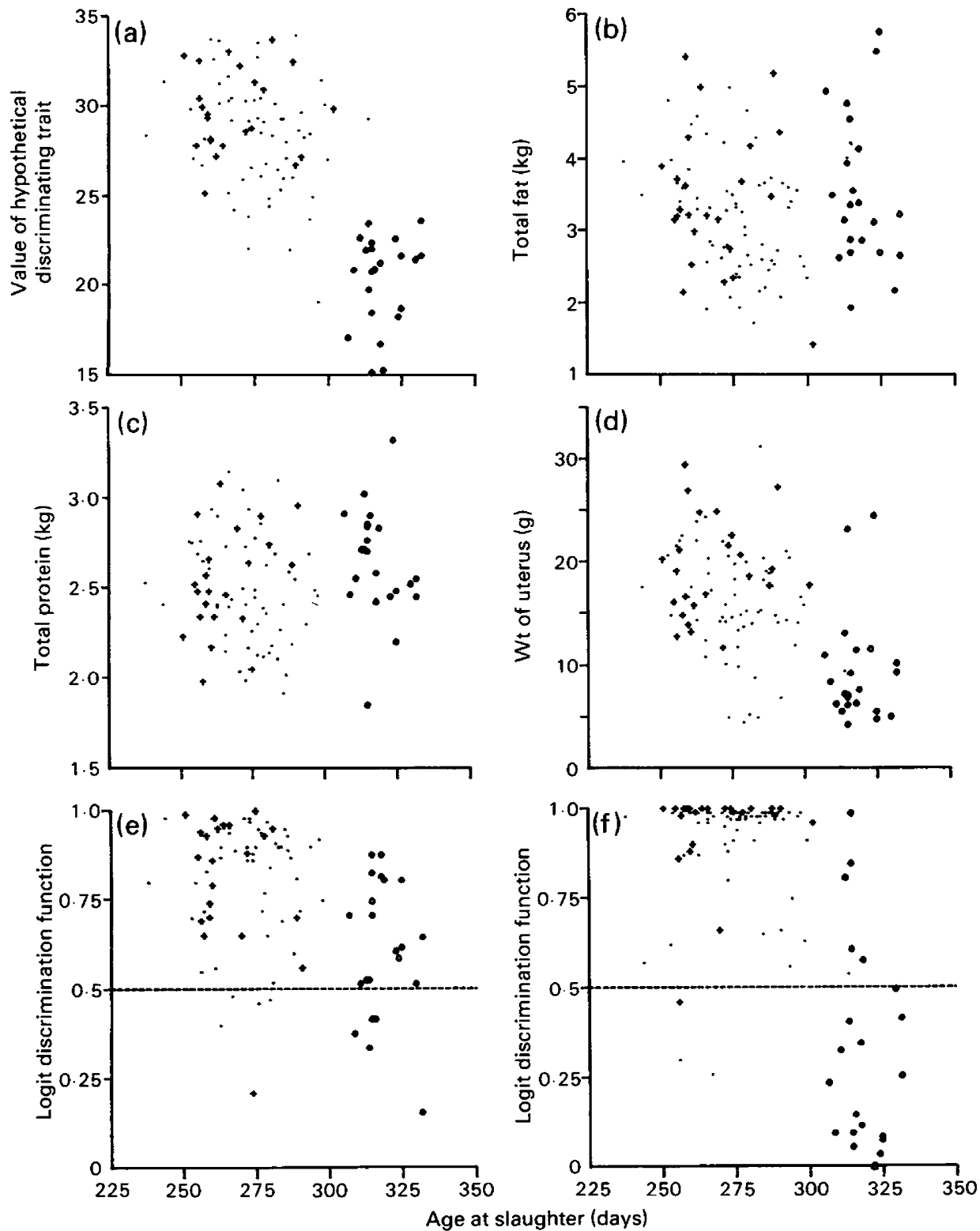

Text-fig. 1. Graphs of a single trait or logit function of traits at slaughter. Each point on the graphs indicates an individual ewe. High nutrition-oestrous group $(+)$; low nutrition-oestrous group $(\bullet)$; low nutrition-non-oestrous group $(O)$. (a) Hypothetical trait providing good discrimination between oestrous and non-oestrous ewes against age at slaughter; (b) weight of total fat against age; (c) weight of total protein against age, (d) uterus weight against age, (e) logit discriminant function of subcutaneous, internal and intermuscular fat, total protein and muscle against age; (f) logit discriminant function of weight of lungs, spleen and stomach against age. 
been graphed against age in Text-fig. $1(\mathrm{e})$ and it can be seen that good discrimination has not been attained. Text-figure l(f) shows the fitted probability obtained using a linear combination of the three organs, lungs, spleen and stomach; the discrimination was reasonable with 9 out of 108 lambs misclassified.

\section{Discussion}

Previous attempts (Frisch et al., 1977; Wilen \& Naftolin, 1977) to find a relationship between body composition and sexual maturation have been based on similarities in composition for early and late maturing female rats in which breeding is not seasonal. In this trial we have made use of the short season (May to mid-July) of oestrus in ewe lambs to compare the body composition of those that did and did not show oestrus in this period.

As far as we are aware these are the first published data attempting to relate direct measurements of body composition to puberty for large female mammals. Despite the significant difference between oestrous and non-oestrous animals in internal fat (when the data were corrected for slaughter weight) we have found that there was little suggestion that the percentage or absolute amount of carcass fat, protein or water discriminated between oestrous and non-oestrous ewe lambs. Frisch \& McArthur (1974) reported minimal weight for height ratios necessary for the onset of menstrual cycles in girls. One can conclude from their data that heavy, short girls menstruate earlier than light, tall girls. While heavy well-grown groups of ewe lambs show a higher incidence of oestrus than do groups of light ewes (Dyrmundsson, 1973, review; Moore, Knight \& Whyman, 1978), height is not associated with oestrus: there was no difference in cannon bone length between oestrous and non-oestrous ewe lambs in this study and that of Stephenson, Dalton \& Kirton (1980).

It might be inferred that our failure to find differences was because the non-oestrous animals were 6 weeks older at slaughter than the oestrous animals and this age difference eliminated any difference in fat content. However, age had no relationship with total or percentage fat when corrected for hot carcass weight. This agrees with Tulloh (1963) who plotted the lamb data of Palsson \& Verges (1952) and concluded that the weight of dissected fat was poorly related to the age and nutritional history of the lambs but was strongly related to empty liveweight, and also with Reid et al. (1968) who found that "a variety of dietary treatments and differences in age failed to influence the body composition of the sheep independently of their effects upon body mass when a continuously positive body energy balance was maintained."

In this study the only single variate which was capable of discriminating between the two types of ewes was weight of the uterus, but as it is the same surge of oestradiol which causes both behavioural oestrus and hypertrophy of the pre-pubertal uterus, as has also been shown in heifers (Desjardins \& Hafs, 1969), this weight would not allow prediction of oestrus in ewe lambs even were it possible to measure it on the live animal.

No reason can be given for the discrimination between oestrous and non-oestrous individuals by the combined variation of stomach, lungs and spleen. The validation of this result must await another set of data.

We thank W. A. Morgan for management and collection of data and Wendy Carter and E. G. Woods for carcass dissections.

\section{References}

Desjardins, C. \& Hafs, H.D. (1969) Maturation of bovine female genitalia from birth through puberty. J. Anim. Sci. 28, 502-507.
Dyrmundsson, O.R. (1973) Puberty and early reproductive performance in sheep. I. Ewe lambs. Anim. Breed. Abstr. 41, 273-289. 
Frisch, R.E. \& McArthur, J.W. (1974) Menstrual cycles: fatness as a determinant of minimum weight for height necessary for their maintenance or onset. Science, N.Y. 185, 949-951.

Frisch, R.E., Hegsted, D.M. \& Yoshinaga, K. (1977) Carcass components at first estrus of rats on high-fat and low-fat diets: body water, protein and fat. Proc. natn. Acad. Sci. U.S.A. 74, 379-383.

Hight, G.K., Lang, D.R. \& Jury, K.E. (1973) Hill country sheep production. V. Occurrence of oestrus and ovulation rate of Romney and Border Leicester $x$ Romney ewe hoggets. N.Z. Jl agric. Res. 16, 509-517.

Kirton, A.H. \& Pickering, F.S. (1967) Factors associated with differences in carcass conformation in lambs. N.Z. Jl agric. Res. 10, 183-200.

Kirton, A.H., Dalton, D.C. \& Ackerley, L.R. (1974) Performance of sheep on New Zealand hill country. II. Growth and composition of wethers of five breeds at three ages. N.Z. Jl agric. Res. 17, 283-293.

Moore, R.W. \& Smeaton, D.C. (1980) Effects of different growth paths from 4 to 11 months of age on Romney hogget oestrus and subsequent production. Proc. N.Z. Soc. Anim. Prod. 40, 27-33.

Moore, R.W., Knight, T.W. \& Whyman, D. (1978) Influence of hogget oestrus on subsequent fertility. Proc. N.Z. Soc. Anim. Prod. 38, 90-96.

Moore, R.W., Bass, J.J. \& Winn, G.W. (1981) Is a particular body composition related to first oestrus in Romney hoggets? Proc. Aust. Soc. Reprod. Biol. 13, 17, Abstr.
Palsson, H. \& Verges, J.B. (1952) Effects of the plane of nutrition on growth and the development of carcass quality in lambs. Part I. The effects of high and low planes of nutrition at different ages. J. agric. Sci., Camb. 42, 1-92.

Press, S.J. (1972) Applied Multivariate Analysis. Holt, Rinehard \& Winston Inc., New York.

Press, S.J. \& Wilson, S. (1978) Choosing between logistic regression and discriminant analysis. J. Am. statist. Ass. 73, 669-705.

Reid, J.T., Bensadoun, A., Bull, L.S., Burton, J.H., Gleeson, P.A., Han, I.K., Joo, Y.D., Johnson, D.E., McManus, W.R., Paladines, O.L., Stroud, J.W., Tyrrell, H.F., Van Niekerk, B.D.H. \& Wellington, G.W. (1968) Some peculiarities in the body composition of animals. In Publication 1598. National Academy of Sciences, Washington DC.

Stephenson, S.K., Dalton, D.C. \& Kirton, A.H. (1980) The relationships of growth, body shape, and body composition to the initiation of oestrous activity in different sheep breeds. Proc. N.Z. Soc. Anim. Prod. 40, 258-267.

Tulloh, N.M. (1963) The carcase compositions of sheep, cattle and pigs as functions of body weight. In Carcase Composition and Appraisal of Meat Animals, pp. 5-1-5-16. Ed. D. E. Tribe. CSIRO, Melbourne.

Wilen, R. \& Naftolin, F. (1977) Pubertal food intake, body length, weight, and composition in the well fed female rat. Pediat. Res. 11, 702-703.

Received 22 August 1984 